\title{
KONSUMSI PAKAN, KONVERSI PAKAN DAN PRODUKSI TELUR AYAM ARAB YANG DITAMBAHKAN TEPUNG DAUN MURBEI PADA PAKAN
}

\author{
Amiruddin. ${ }^{1 *}$, L. Agustina ${ }^{2)}$, Jamilah ${ }^{2}$, \\ ${ }^{1)}$ Mahasiswa Program Strata Satu Departemen Nutrisi dan Makanan Ternak, \\ Fakultas Peternakan, Universitas Hasanuddin. \\ ${ }^{2)}$ Dosen Departemen Nutrisi dan Makanan Ternak, Fakultas Peternakan, Universitas \\ Hasanuddin. \\ Email: amiruddin.beddu@yahoo.co.id
}

\begin{abstract}
ABSTRAC
This study aimed to see the effect of mulberry leaf as a feed additive to evaluate feed consumption, feed conversion and egg production. This study used 48 Arabic Chicken aged 10 months from CV Kuda Hitam Kediri. The composition of the feed consists of mulberry leaf powder, yellow corn, rice bran, fish meal, coconut meal, soybean meal, mineral and vegetable oil. The research had been analyzed using SPSS program version 16. This study used Completely Randomized Design (CRD) (Gaspersz, 1991) consisting of 4 treatments 6 replications, the treatment was R1 (5\% mulberry leaf powder), R2 (7.5\% mulberry leaf powder), R3 (10\% mulberry leaf powder) and R4 (12.5\% mulberry leaf powder), and herbal ingredients $2.5 \mathrm{ml} /$ liter drinking water. The results showed that the use of mulberry leaf with different levels had highly significant effect $(\mathrm{P}>0,05)$ on feed consumption and had no effect on feed conversion and egg production. It can be concluded that the average consumption of feed produced ranged between 107.08-109,74 g /head /day while the average production of eggs in the range of $14.68-16.46 \%$. The average conversion of feed produced ranging from 2.50 to 2.59 . It was concluded that mulberry leaf powder can be added to Arabic chicken feed until level 12,5\%.
\end{abstract}

Keywords: Herbs, Mulberry Leaf, Performance of Arabic Chicken

\begin{abstract}
ABSTRAK
Penelitian ini bertujuan melihat pengaruh pemberian tepung daun murbei dalam pakan terhadap konsumsi pakan, konversi pakan dan produksi telur ayam arab. Ayam arab yang digunakan sebanyak 48 ekor dengan umur 10 bulan produksi CV kuda hitam perkasa Kediri. Komposisi pakan terdiri dari: tepung daun murbei, jagung kuning, dedak padi, tepung ikan, bungkil kelapa, bungkil kedelai, mineral, tepung bulu dan minyak nabati. Data yang diperoleh dianalisis menggunakan program SPSS versi 16. Penelitian ini menggunakan Rancangan Acak Lengkap (RAL) (Gaspersz, 1991) yang terdiri dari 4 perlakuan 6 ulangan, perlakuannya yaitu R1 (5\% tepung daun murbei), R2 (7,5\% tepung daun murbei), R3 (10\% tepung daun murbei) dan R4 (12,5\% tepung daun murbei), tiap perlakuan ditambahkan ramuan herbal $2,5 \mathrm{ml} / \mathrm{liter}$ air minum. Hasil penelitian menunjukkan bahwa penggunaan tepung daun murbei dengan berbagai level berpengaruh nyata $(\mathrm{P}<0,05)$ terhadap konsumsi pakan dan tidak berpengaruh pada konversi pakan dan produksi telur. Rata-rata konsumsi pakan
\end{abstract}


yang dihasilkan berkisar antara 107,08-109,74 g/ekor/hari sedangkan rata-rata konversi pakan yang dihasilkan berkisar 2,50-2,59 sementara rata-rata produksi telur yang di peroleh berkisar 14,68-16,46\%. Disimpulkan bahwa tepung daun murbei dapat di tambahkan pada pakan ayam arab sampai level 12,5\%.

Kata kunci : Ramuan Herbal, Daun Murbei, Performa Ayam Arab

\section{PENDAHULUAN}

Industri peternakan unggas merupakan salah satu penyedia protein hewani yang murah dan mudah di dapat, baik itu berupa daging maupun telur. Masalah utama yang sering muncul dalam dunia perunggasan adalah tingginya harga pakan yang seringkali menyebabkan banyak industri perunggasan mengalami kerugian bahkan sampai gulung tikar. Saat ini banyak peneliti mencari alternatif pakan lokal yang bisa digunakan untuk mengurangi proporsi bahan pakan lain yang di dominasi oleh bahan pakan impor. Pakan merupakan faktor yang paling utama dalam peternakan unggas. Biaya yang dikeluarkan untuk pakan bisa mencapai $70 \%$ dari biaya produksi, oleh karena itu menekan biaya pakan berarti menekan biaya produksi. Alternatif bahan pakan yang biasa digunakan adalah leguminosa karena kandungan proteinnya yang tinggi. Saat ini beberapa studi menemukan bahwa daun murbei memiliki potensi yang besar untuk dijadikan pakan ternak karena kaya akan kandungan protein yaitu 18,43\% (Syahrir dkk., 2009). Selain itu, produksi biomassa murbei juga tinggi produksi biomassa murbei dengan interval defoliasi 90 hari akan mencapai 25 ton bahan kering/ha/tahun (Martin et al., 2008).

Daun murbei kaya akan protein, kalsium, asam askorbat, mengandung karoten, vitamin B1, asam folat dan Vitamin D (Schmidek et al., 2006). Berbagai kandungan nutrien pada daun murbei dapat meningkatkan kualitas pakan yang diberikan pada ayam arab sehingga meningkatkan produksi telur, menurut Wahyu (1992) kuantitas dan kualitas pakan yang diberikan pada ternak sangat menentukan produksi dan kualitas telur baik secara internal maupun eksternal.Obat-obatan juga seringkali meningkatkan biaya produksi karena tingginya harga. Penggunaan ramuan herbal diharapkan mampu menjaga kesehatan ternak dan dapat menggantikan obat komersial, karena kemampuan ramuan herbal terbukti mampu menghambat bakteri Gram positif dan Gram 
negatif (Sulandari dkk., 2007), ramuan herbal tersebut memiliki zat bioaktif berupa curcumin yang terbukti mampu meningkatkan nafsu makan, yang akhirnya akan meningkatkan konsumsi pakan. Daun murbei yang kaya akan protein dapat meningkatkan produksi telur, sementara ramuan herbal yang kaya akan zat bioaktif dapat meningkatkan konsumsi pakan yang diiringi dengan peningkatan produksi telur dapat menghasilkan konversi pakan (FCR) yang rendah sehingga akan lebih efisien. Diharapkan dengan pemberian level daun murbei yang diberikan ramuan herbal dapat memperbaiki konsumsi pakan, meningkatkan produksi telur dan konversi pakan.

\section{METODE PENELITIAN}

\section{Waktu dan Lokasi Penelitian}

Penelitian dilaksanakan pada Bulan Oktober sampai dengan Bulan Desember di Laboratorium Nutrisi Non Ruminansia, Fakultas Peternakan Universitas Hasanuddin, Makassar.

\section{Materi Penelitian}

Alat yang digunakan dalam penelitian adalah kandang cages dari kawat yang terdiri dari 24 petak dengan ukuran panjang $30 \mathrm{~cm}$ x lebar $35 \mathrm{~cm}$ x tinggi $33 \mathrm{~cm}$, timbangan digital, tempat pakan, tempat minum, tempat telur (rak telur), kantong plastik, gelas ukur dan alat tulis menulis.

Bahan yang digunakan dalam penelitian adalah ayam arab umur 10 bulan sebanyak 48 ekor, ramuan herbal cair, tepung daun murbei, jagung kuning, dedak padi, tepung ikan, bungkil kelapa, bungkil kedelai, mineral, tepung bulu dan minyak nabati. Komposisi dan kandungan pakan dapat dilihat pada Tabel 1.

\section{Metode Penelitian}

Rancangan yang digunakan dalam penelitian adalah Rancangan Acak Lengkap (RAL) dengan 4 perlakuan dan 6 ulangan. Masing-masing unit percobaan terdiri dari 2 ekor ayam, sehingga jumlah ayam arab betina yang digunakan adalah 48 ekor. Ramuan herbal pada semua perlakuan di beri sebanyak 2,5 ml/liter air minum. Perlakuan pakan terdiri dari :

$\mathrm{R} 1=5 \%$ Tepung Daun Murbei 
$\mathrm{R} 2=7,5 \%$ Tepung Daun Murbei

R3 $=10 \%$ Tepung Daun Murbei

R4 $=12,5 \%$ Tepung Daun Murbei

Tabel 1. Komposisi Pakan Menggunakan Daun Murbei

\begin{tabular}{lcccc}
\hline \multirow{2}{*}{ Jenis Bahan } & \multicolumn{4}{c}{ Komposisi Pakan Penelitian (\%) } \\
\cline { 2 - 5 } Jagung Kuning & $\mathrm{R} 1$ & $\mathrm{R} 2$ & $\mathrm{R} 3$ & $\mathrm{R} 4$ \\
Dedak Padi & 52,7 & 53,5 & 51,8 & 50,8 \\
Tepung Ikan & 20,0 & 18,0 & 17,5 & 15,5 \\
T. Daun Murbai & 5,5 & 4,5 & 5,0 & 5,0 \\
Bungkil Kedelai & 5,0 & 7,5 & 10,0 & 12,5 \\
Bungkil Kelapa & 5,5 & 4,5 & 4,0 & 5,0 \\
Mineral & 4,0 & 4,0 & 4,0 & 4,0 \\
Tepung Bulu & 1,0 & 1,0 & 1,0 & 1,0 \\
Minyak Nabati & 5,0 & 6,0 & 5,5 & 5,0 \\
Total & 1,3 & 1,0 & 1,2 & 1,2 \\
\hline Protein Kasar (\%) & 100 & 100 & 100 & 100 \\
Energi Metabolis(kkal) & 18,09 & 18,15 & 18,02 & 18,09 \\
Lemak Kasar (\%) & 2804,032 & 2804,12 & 2800,44 & 2800,64 \\
Serat Kasar (\%) & 4,27 & 4,56 & 4,58 & 4,48 \\
Ca (\%) & 4,27 & 4,45 & 4,72 & 4,88 \\
P (\%) & 1,00 & 1,03 & 1,17 & 1,28 \\
\hline Sumber Harti dkk., & 0,31 & 0,30 & 0,30 & 0,30 \\
\hline
\end{tabular}

Sumber: Hartadi dkk., (2015).

Variabel yang diamati dalam penelitian ini adalah :

1. Konsumsi Pakan

Jumlah konsumsi pakan dihitung dengan cara menimbang pakan yang diberikan setiap hari selama seminggu dikurangi pakan sisa pada akhir minggu. Konsumsi pakan ayam buras dapat diketahui berdasarkan rumus (Rasyaf, 2008). Konsumsi Pakan (g/ekor/minggu) = Pakan yang diberikan $(\mathrm{g})-$ Pakan sisa $(\mathrm{g})$ Jumlah ayam (ekor)

\section{Konversi Pakan}

Konversi pakan merupakan suatu ukuran yang digunakan untuk menilai efisiensi penggunaan serta kualitas pakan. Rumus yang digunakan untuk mengetahui konversi pakan adalah sebagai berikut (Rasyaf, 2006).

Koversi pakan $=\underline{\text { Komsumsi pakan }(\mathrm{g})}$

Produksi telur $(\mathrm{g})$ 


\section{Produksi Telur/Hen Day Production (\%)}

Produksi telur dihitung setiap hari selama penelitian. Rumus yang digunakan untuk menghitung produksi telur/hen day sebagai berikut (North and Bell, 1990):

Hen Day Production $(\%)=\underline{\text { Jumlah produksi telur }} \times 100 \%$ Jumlah ayam yang ada

(Perbandingan antara jumlah telur yang diproduksi dengan jumlah ayam yang ada tiap hari dikalikan $100 \%$ ).

Penelitian ini menggunakan Rancangan Acak Lengkap (RAL), data yang diperoleh di analisis menggunakan program SPSS versi 16. di lanjutkan dengan uji jarak berganda Duncan (Gasperz,1991).

\section{HASIL DAN PEMBAHASAN}

Pengaruh penggunaan tepung daun murbei terhadap konsumsi pakan, produksi telur dan konversi pakan ayam arab dapat dilihat pada Tabel 2.

Tabel 2. Rata-Rata Konsumsi Pakan, Produksi Telur dan Konversi Pakan Ayam Arab

\begin{tabular}{cccc}
\hline Perlakuan & $\begin{array}{c}\text { Konsumsi } \\
\text { Pakan } \\
\text { (g/ekor/hari) }\end{array}$ & $\begin{array}{c}\text { Konversi } \\
\text { Pakan }\end{array}$ & $\begin{array}{c}\text { Produksi Telur } \\
\text { (\% Hen Day) }\end{array}$ \\
\hline R1 $(5 \%)$ & $107.08 \mathrm{~b} \pm 0,97$ & $2,50 \pm 0,08$ & $15,33 \pm 6,08$ \\
R2 $(7,5 \%)$ & $108,74 \mathrm{a} \pm 1,66$ & $2,59 \pm 0,10$ & $16,46 \pm 5,55$ \\
R3 $(10 \%)$ & $107,99 \mathrm{ab} \pm 1,10$ & $2,53 \pm 0,21$ & $14,68 \pm 6,88$ \\
R4 $(12,5 \%)$ & $109,08 \mathrm{a} \pm 0,83$ & $2,58 \pm 0,11$ & $15,07 \pm 7,59$ \\
\hline
\end{tabular}

\section{Konsumsi Pakan}

Hasil analisis satatistik (Tabel 2) menunjukkan bahwa penggunaan tepung daun murbei berpengaruh nyata $(\mathrm{P}<0,05)$ terhadap konsumsi pakan ayam arab. Penambahan tepung daun murbei dalam pakan sampai dengan level 12,5\% memberikan pengaruh terhadap konsumsi pakan. Konsumsi pakan merupakan faktor penunjang untuk mengetahui penampilan produksi, semakin tinggi ternak mengkonsumsi pakan yang disajikan maka akan semakin banyak pula nutrisi pakan yang akan dicerna untuk menunjang produksi. Hal ini didukung oleh Abun (2005) menyatakan bahwa konsumsi pakan meningkat akan memberikan kesempatan pada tubuh ternak untuk meretensi zat-zat makanan yang lebih banyak guna untuk kebutuhan produksi. 
Uji jarak berganda Duncan terhadap perlakuan diperoleh hasil bahwa perlakuan R3 tidak berbeda perlakuan R1, R2 dan R4 dan R1 lebih rendah dari perlakuan R2 dan R4. Hal ini disebabkan oleh tingkat kesukaan ayam terhadap pakan perlakuan yang berbeda-beda. Tabel komposisi pakan (Tabel 1) memperlihatkan terdapat perbedaan jumlah penambahan tepung daun murbei pada setiap perlakuan dimana pemberian tepung daun murbei pada level $12,5 \%$ menghasilkan konsumsi pakan yang paling tinggi yaitu 109,08g.

Berdasarkan hasil analisis diketahui bahwa pemberian tepung daun murbei pada level 12,5\% konsumsi pakan ayam arab paling tinggi. Tingkat konsumsi pakan dipengaruhi oleh bentuk fisik pakan dimana komposisi pemberian jagung kuning (Tabel 3) pada perlakuan R4 sebesar 50,8 \% dan tepung daun murbei $12,5 \%$ lebih tinggi dari tiga perlakuan yang lain, tepung daun murbei juga memiliki aroma yang khas, Agustina dan Purwanti (2012) menyatakan bahwa zat-zat pembawa cita rasa dan aroma (flavor) yang akan diterima oleh sistem penerima adalah perangsang metabolit yang dapat menimbulkan perubahan selera makan secara fisik.

Ramuan herbal yang digunakan bersifat antimikroba karena mengandung zat bioaktif yang dapat menekan bakteri patogen dalam saluran pencernaan yang berimbas pada perbaikan pencernaan (Agustina, 2006). Ramuan herbal mengandung minyak atsiri dan kurkumin yang dapat meningkatkan kerja organ pencernaan, merangsang dinding empedu mengeluarkan cairan empedu dan merangsang keluarnya getah pankreas yang mengandung enzim amilase, lipase dan protease untuk meningkatkan pencernaan bahan pakan karbohidrat, lemak dan protein (Winarto,2003), oleh karena dosis ramuan herbal diberikan pada level yang sama untuk semua perlakuan sehingga memberikan pengaruh yang sama pada setiap perlakuan, berbeda dengan tepung daun murbei yang diberikan dengan level yang berbeda untuk semua perlakuan sehingga memberikan pengaruh yang berbeda pula.

\section{Konversi Pakan}

Analisis statistik menunjukkan bahwa perlakuan tidak memberikan pengaruh yang nyata $(\mathrm{P}>0,05)$ terhadap konversi pakan. Konversi pakan merupakan salah satu aspek untuk menilai efisiensi penggunaan pakan yang 
dikonsumsi. Rasyaf (2012), konversi pakan menujukkan gambaran tentang efisiensi penggunaan pakan di tinjau dari aspek teknis. Konversi pakan juga dapat di pengaruhi oleh konsumsi (Berri et al., 2004)

Berdasarkan Tabel 2, pengaruh penambahan tepung daun murbei pada level yang berbeda menunjukkan adanya kecenderungan konversi pakan yang baik diperoleh pada perlakuan R1 (penambahan tepung daun murbei 5\%) dengan rata-rata konversi pakan sebesar 2,50 (Tabel 2). Nilai konversi pakan yang diperoleh cenderung baik dibandingkan dengan nilai konversi pakan yang di peroleh pada penelitian Permanan, (2012) sebesar 4,47. Konversi pakan yang rendah menunjukkan semakin tinggi efisiensi penggunaan pakan. Hal ini di dukung oleh pendapat Mulyono (2004) bahwa konversi pakan yang rendah menunjukkan gambaran tentang efisiensi penggunaan pakan yang baik.

Konversi pakan sangat penting diperhatikan karena erat kaitannya dengan biaya produksi. Nilai konversi pakan diperoleh melalui perbandingan antara jumlah pakan yang dikonsumsi dengan jumlah produksi telur yang diperoleh (g). Berri et al., (2005) menyatakan konversi pakan ayam selain tergantung pada kecepatan pertumbuhan dan konsumsi pakan, juga ditentukan oleh besar ukuran tubuh, temperatur lingkungan dan kesehatan ayam.

\section{Produksi Telur}

Perhitungan sidik ragam menunjukkan bahwa pemberian tepung daun murbei tidak berpengaruh nyata $(\mathrm{P}>0,05)$ terhadap produksi telur. Dari hasil penelitian diperoleh produksi telur tertinggi pada perlakuan R4 (penambahan tepung daun murbei $12.5 \%$ dan ramuan herbal $2.5 \mathrm{ml}$ ) dengan konsumsi pakan tertinggi mencapai 109,08 (g/ekor/hari). Amrullah (2003) berpendapat bahwa faktor utama yang mempengaruhi produksi telur adalah jumlah pakan yang dikonsumsi dan kandungan zat makanan dalam pakan. Penggunaan tepung daun murbei dengan konsentrasi $12.5 \%$ adalah penggunaan level yang paling efisien ditinjau dari segi produksi. Tingginya produksi telur pada perlakuan R4 juga didukung oleh kandungan protein pakan yaitu 18,15\% (Tabel 2). Hal ini sejalan dengan pendapat Suprijatna (2005) bahwa presentase produksi pada saat periode produksi nyata dipengaruhi oleh taraf protein selama periode produksi. Yusuf 
(2002) menambahkan bahwa produksi telur dapat dipengaruhi oleh tingkat protein di dalam pakan.

Penambahan ramuan herbal dapat meningkatkan daya tahan tubuh ternak sehingga ternak akan lebih sehat, hal ini terlihat dari tidak adanya ternak yang mati selama penelitian. Zainuddin dan Wakradihardja (2001) menyatakan ternak akan lebih sehat karena memiliki daya tahan tubuh yang lebih baik dengan adanya ramuan herbal yang diberi dalam bentuk cair. Ramuan herbal sebagai pengganti antibiotik sintetik berfungsi memperbaiki penyerapan nutrisi pakan melalui peningkatan imunitas dan keadaan usus halus, selain itu ramuan herbal dapat meningkatkan efisiensi pakan (feed efficiency) dan berproduksi secara maksimal (Waldroup et al., 2003).

\section{KESIMPULAN}

Berdasarkan hasil penelitian yang diperoleh, dapat di simpulkan bahwa tepung daun murbei dapat di tambahkan pada pakan ayam arab sampai level $12,5 \%$.

\section{DAFTAR PUSTAKA}

Abun. 2005. Efek Ransum Mengandung Ampas Umbi Garut Produk Fermentasi oleh Kapang Aspergillus niger Terhadap Imbangan Efisiensi Protein dan Konversi Ransum pada Ayam Broiler. Laporan Penelitian. Fakultas Peternakan Universitas Padjadjaran.

Agustina, L. 2006. Penggunaan Ramuan Herbal sebagai Feed Additive untuk Meningkatkan Performans Broiler. Prosiding Lokakarya Nasional Inovasi Teknologi dalam Mendukung Usaha Ternak Unggas Berdaya Saing. Pusat Penelitian dan Pengembangan Peternakan, Bogor. Hal.47-52.

Amrullah, I. K. 2003. Nutrisi Ayam Petelur. Lembaga Satu Gunung Budi. Bogor Gaspersz, V. 1991. Metode Perancangan Percobaan. CV.Armico. Bandung

Hartadi, H., S. Reksohadiprodjo dan A. D. Tillman. 2015. Tabel Komposisi Pakan Untuk Indonesia. UGM Press. Yogyakarta.

Martin, G. J., F. Reyes, I. Hernandezand and J. E. Benavides. 2008. Agronomic Studies With Mulberry in Cuba. FAO. Roma.

Mulyono, S. 2004. Beternak Ayam Buras Berorientasi Agribisnis. Penebar Swadaya. Jakarta 
North and Bell. 1990. Commercial Chicken Production Manual, New York

Permana, E. 2012. Respon Ayam Arab (Gallus turcicus) dan Ayam Kampung (Gallus gallus domesticus) terhadap pPemberian Tepung Daun Katuk (Sauropus androgynous) pada Ransum Berserat Kasar Tinggi. Skripsi. Fakultas Peternakan, Institut Pertanian Bogor. Bogor.

Rasyaf, M. 2008. Panduan Beternak Ayam Pedaging. Jakarta : Penebar Swadaya.

Rasyaf, M. 2006. Manjemen Peternakan Ayam Broiler. Jakarta: Penebar Swadaya

Schmidek, A., R. Takahashi, A.N. de Medeiros, and K.T. de Resende. 2006. Bromatological Composition and Degradation Rate of Mulberry in Goats. In Mulberry for Animal Production, FAO Animal and Health Production Paper 147, Sanchez MD ed (FAO, Rome), pp. 207-212.

Sulandari, S., M. S. A. Zein, S. Paryanti, T. Sartika, M. Astuti, T. Widjastuti, E. Sudjana, S. Darana, I. Setiawan dan D. Garnida. 2007. Sumberdaya Genetik Ayam Lokal Indonesia. Keanekaragaman Sumberdaya Hayati Ayam Lokal Indonesia: Manfaat dan Potensi. Pusat Penelitian Biologi Lembaga Ilmu Pengetahuan Indonesia. Jakarta. Hal: 45-67

Suprijatna, E. U, Atmomarsono. R, Kartasudjana. 2005. Ilmu Dasar Ternak Unggas. Penebar Swadaya, Jakarta

Syahrir, S., K.G. Wiryawan, A. Parakkasi, M. Winugrohoc dan O.N.P. Sarib. 2009. Efektivitas daun murbei sebagai pengganti konsentrat dalam sistem rumen in vitro. Med.Pet., 32 : 112-119.

Wahyu. J. 1992. Ilmu Nutrisi Ternak Unggas. UGM-Press. Yogyakarta.

Winarto, W. P. 2003. Khasiat dan Manfaat Kunyit. Agromedia Pustaka.Jakarta.

Yusuf, M. 2002. Perubahan Warna Kuning Telur Itik Lokal Akibat Penggantian Beras dengan Jagung sebagai Sumber Energi dalam Pakan. Skripsi. Fakultas Peternakan. Institut Pertanian Bogor. Bogor.

Zainuddin, D dan E. Wakradihardja. 2001. Racikan ramuan tanaman obat dalam bentuk larutan jamu dapat meningkatkan kesehatan hewan serta produktifitas ternak ayam buras. Seminar Nasional Tumbuhan Obat Indonesia XIX. April 2001. Balai Penelitian Tanaman Rempah dan Obat. Bogor.

Waldroup, P. W., E. O. Rondon and C. A. Fritts. 2003. Comparison of bio-mos and antibiotic feeding progams in broiler diets containiig copper sulfate. International Journal of Poultry Science 2 (1) : 28-31. 